\title{
The Semantics of Taqiya (Religious Prudence) in Shiite Narrations Based on Izutsu Method
}

\author{
Reza Jafari ${ }^{1}$, Gholamreza Raeisian ${ }^{2}$, Mahdi Jalaly ${ }^{2}$ \& Seyyed Mohammad Emamzadeh ${ }^{2}$ \\ ${ }^{1}$ Ph.D student, Ferdowsi University of Mashhad, International Branch, Mashhad, Iran \\ ${ }^{2}$ Ferdowsi University of Mashhad, Mashhad, Iran \\ Correspondence: Gholamreza Raeisian, Mashhad Ferdowsi University, International Branch, Iran. E-mail: \\ Raeisian@um.ac.ir
}

Received: May 29, 2016 Accepted: June 26, 2016 Online Published: August 30, 2016

doi:10.5539/jpl.v9n7p184 URL: http://dx.doi.org/10.5539/jpl.v9n7p184

\begin{abstract}
The word "تقيه" (reservation) has been stated in Arabic language before Islam means to abstain, keep and hide. This word before the advent of Islam has been used as a customary word for the act of expressing or concealing the belief and opinion to protect their life or property or whatever is honorable for the user of reservation. Reservation passed certain semantic developments and transformations in Shia after Islam and finally was turn to a religious - moral word. The use of the reservation became common due to the conditions of social - political life of Innocent Imams (peace to be upon them) and their followers in the period of Imam Baqir and Imam Sadiq (peace to be upon them). It was used in the meaning of hiding the truth and not stating to believe in it against the opponents in order to abstain from religious or secular loss. Thus, was considered in the category of Shia religious - moral vocabulary. Reservation is of the first level terms of language according to Izutsu method and describes an objective and real concept. Its first semantic core is without valuation. Some elements have been considered at the semantic core of the reservation that faith and security is of the most important of them.
\end{abstract}

Keywords: Semantics of reservation, Diachronic and Synchronic semantics, Shia religious - moral terms

\section{Introduction}

Reservation is of the religious terms and teachings, which is very important especially in Shiism religion. This subject has been always focused since the first centuries $\mathrm{AH}$ and has been the position of anecdotal, and theological and jurisprudential discussions (See, for example Najashi, p. 38, 58, 253, 330, 340, 351, 354, 391, 396; Tousi, Al-fehrest, p. 58, 112; Encyclopedia of Islamic world, following reservation entry). The present article analyzes the concept of reservation and its surrounding concepts and vocabulary. But the method to investigate the subject and find answers to this problem is new.

In this article, we intend to investigate and analyze semantic structure and concept of reservation by interpretative method of Toshihiko Izutsu in Shia narrations. So far what has been written about the reservation have emphasized on theological and jurisprudential definitions. Less works can be found that has investigated this subject by passing through new techniques and methods of semantics. Comparison of various usages of reservation in narrations and its relations with other terms and concepts will open a new horizon of recognition of this concept for us through investigating contrasts and companions except the one that is considered in Izutsu method.

Reservation is a moral concept because is a voluntary action and to be placed on the scales of good and bad measurement and moral judgments value. More clearly, when we talk about the reservation, this issue should be posed whether reservation is morally permissible or impermissible and weather is good or bad. On the other hand reservation is a religious concept and jurisprudential rulings and works are arranged on it. Therefore, it can be said that reservation is a religious - moral concept.

\section{Research Problem}

Whether reservation belongs to the first level of language or second-level? In other words, whether the reservation describes an objective and real concept in the first stage and without valuation or belongs to the second level of language and has valuation? Does this valuation prevail descriptive aspect and foremost denounces or praises an act? What semantic transformations have been passed in reservation? What are its main 
semantic elements or element?

\section{Hypothesis}

Reservation has been changed to religious - moral terms after Islam and some elements have been added to its semantic core. This term belongs to the first level of language and foremost describes an objective and real meaning. Faith and security form real semantic core of reservation.

\section{Research Methodology}

This research has been conducted by Toshihiko Izutsu method. It has been described in detail in two Books of God and Man in Quran (translated by Ahmad Aram, Tehran, 2002) and moral - religious concepts of Holy Quran (translated by Fereydoun Badrehii, Tehran, 2009). Izutsu method has been investigated in several articles and researches. But here we illustrate his method due to the subject of article, because it is clear that the use of Izutsu method will have differences due to research subject. It should be noted that Izutsu method is used in the present article in the semantics of moral - religious concepts of Qur'an and for semantic analysis of reservation in narrations.

Izutsu himself has clarified that almost anything that is thought to be the holder of semantic; it can be the subject of research in this kind of semantics in general (p. 3 God and Man). A comprehensive description of Izutsu method cannot be done by the present article, and we only get into this subject to the extent that is necessary for understanding the present research, and indicates our method in interpretation of narrations. Another issue which addressing to it is out of the present article is utilizations that Izutsu has used in his own method from other scientists. He himself has talked about this subject in his works. (For example, see: p. 5 God and Man in the Quran)

\subsection{Semantics}

Izutsu has called his work in the analysis and interpretation of the concepts of the Holy Quran, "semantics". He explained that what the purpose of semantics is. he states what is now called semantics is confusing and complicated (p. 2 ibid.), and this is because of scientific semantics that deals with the broadest meaning of the word and includes important issues that scientists follow in various specialized fields such as pure linguistics, sociology, anthropology, and etc.

In fact, semantics is not yet available as an organized science. We only encounter with number of semantics theories that have not yet be able to create a particular and official scientific field. Thus, "Whoever speaks of semantics, he tends to makes himself obliged to define and understand this word in the way that he likes."(p. 3 God and Man) Izutsu himself is also one of them and has a specific definition of semantics.

In his view, semantics is an analytical research and study on keywords of language to re-identify the destination of a people's worldview that use their language not only such as means of speaking and thinking, but also as a means to image and interpret the world around them. This semantics is the knowledge of research in the nature and structure of the worldview of a people and a nation in a specific period of their history. This is done by analyzing methodology of concepts and major cultural notions of that nation and key words of the language of that nation (p. 4 Ibid.)

Thus, we in fact make clear the corner of notions and perceptions of a nation about the world around it, including cultural, political, and social subjects and so on by semantic analysis of a linguistic unit. Izutsu semantics reveals a kind of ontology through this. This means that we achieve the attitude of that people of what is around them by semantic analysis, and we observe the universe or a corner of the universe and its components and their relationship and at least what they think "exists" from their perspective (See: p. 4, ibid.)

This ontology is different from the philosophy that a philosopher has as an abstract thinking, regardless of objective facts, and in a tangible and objective-oriented and vainglorious view on real or more correct world: what the users of that language consider real and perceive from their world around them. For example, in the present article we reach a view and structure of objective perception and viewpoint of reservation users - who are mostly the same Shias - around them through semantics of reservation and its relationship with other concepts and words and through other stages that have been defined in this semantics.

This view makes clear for us a corner of the "real world in the view of Shias" in a certain period to the extent that it is related to this word and its surrounding words. In fact, identification of a part of Shias' perception from the real world is indebted to semantics of concepts such as reservation. We can achieve a view of their worldview by juxtaposing key words of Shias' religious texts and semantic analysis of them and identification of a notion network which has been rose among this. 


\subsection{Continuity and Vocabulary System}

According to Izutsu's view, words and notions in texts such as the Quran - and Shia narrations in our subjecthave a communication system that take their tangible and concrete meaning from total of this system. The same system is made by relationships of these words with each other. Words have links with each other in this system and change the meaning of each other (See p. 5 and 6 of God and Man). There are several factors in the birth of a meaning for a word and its transformation. It's not that the users of a language just choose a word against an object, and the word then to be used for the object. Use of a word for an object and meaning passes a process like the process of children's language learning (p. 28 and 29, moral concepts), and has a deep relationship with other words and objects and cultural and emotional factors. Thus, reaching its objective meaning is not possible regardless of the semantic system of that language and meaning of the related words. In other words, the concepts and words jostle each other, and it should never be considered that they have been used apart from each other and independently. Thus, the meaning of them is achieved by regarding to a system that has been emerged from their relationship with each other. For example window in a building makes a meaning in the user's mind that the same window apart from that building and other components and conditions does not make the same meaning. User's perception from a particular building window is related to the meaning and location of the building, the building form and other components, and even moods and emotions of the user.

The relationship and link of words in semantic system organize rings and groups. These groups are also linked with each other, similarly; and an organized whole and complex network and imaginary integrations are achieved from total of them (p. 6 of God and Man). Individual semantics of words depends on considering totality of this system and links that its groups and words have with each other. Words in isolated and single way and regardless of the presence of this system have a meaning different from the meaning that they have in the aforementioned system. Words and key words used in the Quran and narrations were not born at once. They were also used in Arabic language before Islam but belonged to other notional systems and personal words (p. 2 of God and Man). They were used in the other structural system after Islam and were changed to other notional network and their relationships were transformed. This was strange in the view of pagans of Mecca. (p. 6 of God and Man) Izutsu gives the word of Allah as an example to make clear this theory.

Allah was being also used in pre-Islamic Arabic literature. It can be said that at least some individuals or tribes have believed in a God called Allah. He was Lord of Lords in their view, as the Holy Quran in the verse " ما نَعْبُدُهُ

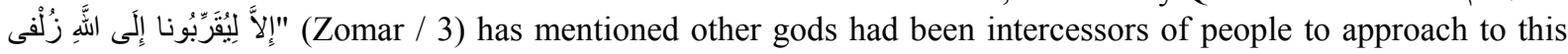
Supreme Lord. Islam abolished this system and showed another position for Allah and created other relationships between its related words. Other gods disappeared and Allah was placed at the center of a conceptual and notional system and structure. Allah is the only source of all being and active forms of man. Thus all being and objects of the universe found a new position and order and rating. (See p. 8 and 9, God and Man)

\subsection{Semantic Core: Descriptive and Valuation (First and Second Level Terms)}

According to Izutsu's view, the system that determines real property of a society's moral language is constituted of first level terms of moral language. The words of this system are descriptive at the first level, which means they describe and report an objective and real behavioral and moral state without judging about it. For example, the word "منقى" (Pious) at the first level speaks about an entirely objective and real features in a person, which can be referred in a tangible and concrete way and has a descriptive content, and does not speak of good and evil, or the adjective of "سخى"(Generous), which describes a kind of generosity, and has a completely objective meaning without judging about it.

The first semantic core of such words is the same descriptive meaning; however a kind of value judgment may be also seen in them in the next look. So "Generous" is descriptive at the first level and is valuation at the second level. The term "كفر"(infidelity), which is of the most important valuation words, is also of this group. Although valuation halo surrounds this word in such a way that it is not merely descriptive word, but at the first level, the meaning of "infidelity" is entirely objective and real, which is: ingratitude to divine blessings.

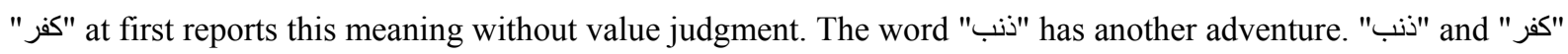
may eventually guide to a similar mode in man, and have a same instance. But "ذنب "نكا" condemns an act because it is of the negative class, therefore is different from "كفر", and can be said that its main semantic core is valuation, not descriptive. Words and terms such as "ذنب" (sin) can be considered meta-language of ethics. (p.44)

According to Izutsu's view, these two levels of meaning should be separated from each other to achieve the main semantic core of word. Although these two meanings have been mixed meaning in a word, separating them theoretically is possible and necessary. The main role of the second level vocabulary is classification. They are 
more used for classification of various descriptive properties. They place moral terms and adjectives in categories with different values, and state that which adjective is good or bad in the view of users of this language. But the first level vocabulary organizes totality of moral system of a people along with each other. This system and the relationships between its terms must be analyzed to achieve moral understanding of a people. (p. 40)

\subsection{Diachronic and Synchronic Research}

Moral - religious vocabulary of a language can be investigated from two different points of view that are known in modern linguistics with the following terms:

1) Diachronic: diachronic is the study of linguistic vocabulary of a nation from the standpoint that emphasizes on the element of time. In this study, the process of transformation and expansion of meanings and development of semantics of terms is examined in different periods of time such as historical process. Briefly, in this method, changes and transformations of linguistic units are examined in certain time periods. (Izutsu, God and Man, 39, Robins, 418) Izutsu considers three main benefits for this method in the subject of semantics of moral - religious terms of Quran:

Firstly, it gives us a deeper and more comprehensive vision and makes clear important aspects of theoretical issues related to the semantics of the intended words. Secondly, no doubt expansion and transformation of most Islamic moral - religious vocabulary have occurred over time and in Islamic period. Studying semantics of these words in the pre-Islamic period and after that gives us this opportunity to find out which property has been added to or reduced during the Islamic period. We achieve more knowledge about the meaning of word in both periods, and finally a synchronic semantics through comparison.

Thirdly, diachronic semantics makes it possible for us to find out the advantages and limitations of each of them by comparing it with synchronic semantics, through which we achieve a combined method from both. (See: Man and God, p. 38 and 39) approach in this method is that we cut different layers or levels of a language at different stages of history, and compare the transformations and changes of the vocabulary in them with each other. Time level becomes short and long depending on the purpose of semantic analysis. (ibid. 42)

2) Synchronic: In this method, we reach the meaning of vocabulary only in a time-consuming selected layer regardless of historical changes and transformations that they have passed (Robins, 418). Izutsu himself clarifies it (see: Man and the Quran, 39) and has also shown in his semantic analyzes that he has utilized combination of this method with diachronic method, and has used both of them together. For example, when examining the moral term of "سخاوت in the Quran, he has examined and compared semantic transformations and changes in two periods of time of ignorance and early Islam, as well as has independently analyzed the meaning in the early period of Islam and regardless of its historical destiny in a synchronic way. (See: moral concepts, 153-169)

However, it seems that he sometimes have preferred one of these two methods over the other. For example, Izutsu in examining the word "لآل (Allah) has used diachronic method - period of after Islam - for its semantic analysis because this word - with its Islamic concept - has had no companion and successor in time of ignorance. (Semantic use of concepts related to time in explaining the Quran, 129 and 130) This article has also utilized the same method in semantics of "تقيه" (reservation).

\section{Lexical and Idiomatic Meaning of "تقيه" (Reservation)}

The word "تقيه" is from the material "V - Q - I", infinitive or action noun Fayyumi, Al-Mesbah Al-Monir, vol. 2, p. 669; Homeiri, Shams Al-olum, vol. 2, adequately addressed, 758), and is meant to avoid, preserve and hide (Johari, Al-sahah, vol. 6, p. 2527; Ibn Manzur, Lesan Al-Arab, vol. 15, p 401 and 402). Commentators, theologians and jurisprudents have offered almost similar idiomatic definitions from it according to their perceptions from the verses and narrations, socio-political conditions of Muslim sects, and their viewing angle (for example, see: Tabari, Jame Al-baian, vol. 3, pp. 152 -153, Sarakhsi, Al-mabsut, vol. 24, p. 45; Khoei, Al-tanqih, vol. 4, p 253 ; Makarem, Al-qavaed Al-feqhieh, vol. 1, p. 393; vol. 3, p. 12 - 13, Safari, role of reservation in inference, pp. 46-53)

Among these, it is useful to say that "تقيه" reservation is to hide the truth and not stating to believe in it against the opponents in order to avoid religious or secular loss (1414, p. 137; also see: Fazel Meqdad, p. 377; Amin, p. 185; Encyclopedia of Islam World, following the entry for reservation. It can be said that the elements of hiding the truth or stating its contrary, and fending off religious or secular loss can be seen in all these definitions.

\section{Historical, Quranic and Narrative Background and Frequency of Reservation}

According to the verses of Quran, background of act of reservation reaches the period before the Holy Prophet 
and has also continued at the time of that Holiness. The Holy Quran has mentioned a person as a believer of people of Pharaoh; (Ghafer, 28) who has hidden his faith in God in the court of the Pharaoh of Egypt, and even it has not used the term reservation, but commentators have considered the act of believer of people of Pharaoh as reservation, (For example, see: Tusi, Qortobi, Soyuti, following the verse).

According to the interpretative sources, verse 106 of Surah of Nahl about reservation of Ammar ibn Yaser and his pretending to atheism to become free from torture of Mecca idolaters, and the permission of this act has been also revealed at the time of the Holy Prophet. (Tabresi, Qortobi, following the verse) verse 28 of Al-Imran also has allowed Muslims of early Islam to reservation in order to fend off pagans' risk in the case of an intense fear of loss by them. However the term reservation has not been mentioned here too (For example, see: Toosi; Fakhr Razi; Nasafi; Soyuti, following the verse). According to historical sources after the migration of the Prophet to Medina, some immigrants for going to Mecca and bringing their properties asked the Holiness for permission to express some words in reservation in order to satisfy paragons.

(See Halbi, vol. 3, p. 51, 52; Encyclopedia of Islam World, following the entry) it is also implied from heresiographical sources (see: Shahrestani, 1, 124-125), the narrations of innocent leaders (see: Continue the article, as well as independent works that have been written about reservation at that time (for example, see: Toosi, Al-fehrest, p. 58, 112) that the reservation has been posed and discussed after the Prophet's death. Shias in the Omayyad and Abbasid periods were forced to reservation in many conditions because of political and social pressures. They were known to reservation more than other religions. So some Sunni writers have considered Sunni as of the weaknesses of Shias, but Shia scholars have responded to their criticisms (for description and detail see: The Encyclopedia of the Islamic world, following the entry)

Despite the use of the word reservation has not been said in the Quran and only the act of reservation has been mentioned in this scripture, this word and its importance has been stated in many narrations. Numerous narrations have been said in the most authentic narrative source of Shia, Kafi, in a Bab with the same title (Koleini, 2, 217 -222), and also sporadically in Babs such as Bab Al-ketman (ibid. 2, 223), Bab Mash Al-khaf (3, 32), Bab Al-sounnah fi Haml Al-jenazeh $(3,168)$ and so on (See: continue the article).

\section{Semantics of Reservation}

As mentioned above, the present article utilizes Izutsu mixed method in semantics of reservation, and deals semantics from two synchronic and diachronic viewpoints. It is implied from historical sources that the word reservation was being used among Hejaz Arabs at the time of the Holy Prophet (PBUH). But there is no authentic evidences showing that this word has had religious - moral meaning, and the reservation has being implicated as a religious act. This is clear that the word reservation has been used in the meaning of concealment of belief among Hejaz Arabs to protect life or property.

Historical narrations can be found, which have mentioned the term reservation with the same meaning, such as the narration that has been narrated from Ibn Ishaq (Hagiography writer of 2nd century AH) about the adventure of Battle of Badr. According to this historical narration, a group of Islam Meccans hid themselves and were forced to join with paragons of Mecca with the intension to battle with the Muslims in the Battle of Badr. The word reservation has been mentioned in this narration for act of this group (Emtae Al-asmae, vol. 1, p. 118). The word reservation has been also mentioned in the following Qodsi Hadith as an act of the true believers to keep their lives:

>ان الله عز و جل يقول: ويل للذين يختلون الدنيا بالدين، و ويل للذنين يقتلون الذين يامرون بالقسط من الناس، و ويل للذين بسير المؤمن فيهم بالتقية؛

Verily, Allah, Exalted and the Sublime says: Woe to those who hijack world by faith, and woe to those who kill the people who enjoining good, and woe to those who a believer walks among them with reservation." (History Ya'qubi / translation, vol. 1, p. 486)

إان الله عز و جل يقول: ويل للذين يختلون الدنيا بالدين، و ويل للذين يقتلون الذين يامرون بالقسط من الناس، و ويل للذين يسير المؤمن فيهم بالتقية؛

This narration on the assumption of authenticity narrates about the reservation among Muslims themselves. Two statements have been expressed in this narration. According to the first statement, a group of members of the Muslim community have used religion as the means to reach wealth and power. It is clearly implied from the tenor of the narration that they are not believers in the Divine religion, and their pretending to religion takes place with the goal of reaching the world. According to the second statement, they are trying to perish well-wishing faithful Muslims who are incompatible with this dissonance, so the second group is forced to choose the way of reservation in dealing with the first group.

The remonstration that is evident in this narration is on the first group, not the second group. The narration has implicitly considered allowable the reservation in these conditions. However, there is nothing in the narration 
indicating that reservation is a religious or moral act, and the use of the term reservation is in such a way as if this term had been of common terms of that time in Arabic language. On the other hand, companion of reservation with enjoining good and forbidding evil in the narration is not in a way that reservation can be considered a term and an act with moral and religious valuation like as enjoining good and forbidding evil. The term reservation has been also used in some historical narrations even for conversion to Islam for hypocrisy, including:

$$
\text { |او أسلم حينئذ بشر كثبر من أهل المدينة و من ثم دخل عبد الله بن أبيّ بن سلول و جماعته من المنافقين في دين الإسلام تقبّة؛ }
$$

And at this time many residents of Medina converted to Islam and thus, Abdullah ibn Abi ibn Salul and a group of hypocrites converted to Islam for reservation." (Emta Al-asma, vol. 1, p. 117; Ansab Al-ahraf, vol. 5, p. 390)

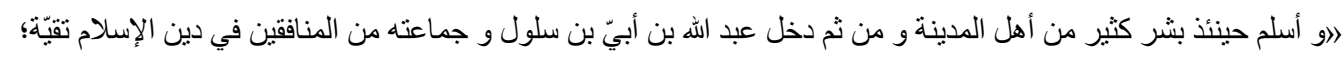

Reservation in this historical narration not only has a positive moral - valuation, but also has a negative "نفافق" (hypocrisy) has been derived from the word "نفاق" (hypocrite), and hypocrisy is of the important moral vices in Islam moral system. it may be concluded from comparison of this historical narration with the aforementioned Qodsi Hadith that reservation is neutral in terms of valuation, and it has being taken its positive or negative connotation depending on the usage case, and has not had a position in the system of religion - moral terms. This is because the reservation in that narration is companion the meaning of faith and derived from the word faithful.

Thus, if the reservation was being used to conceal religious faith, has had a positivity, and in the case that was being used to lure Muslims and believers and apparent conversion to Islam, it has had a negativity. This proves that the reservation alone was not religious term, and it has been taking its moral and religious charge from actual and Maqalieh evidences. Reservation has been still used among Sunnis with the same meaning in the centuries after the migration. They have called pretending to doctrinal accompaniment because of fear as the reservation, as Zahbi, historian of eighth century $\mathrm{AH}$, has also considered even pretending of the dhimmis to Islam as reservation.

Zahabi has mentioned the conversion of the Jews to Islam after the conquest of the land by the muwahhidan interpreted as reservation in a historical narration: According to this historical quote, muwahhidan offered a choice to dhimmis to either convert to Islam or they are killed or they exile. Among them most of the Jews converted to Islam because of reservation and Christians left the country:

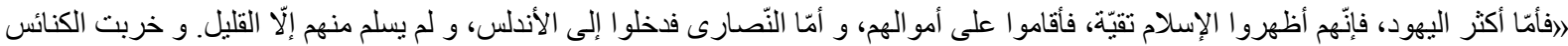

$$
\begin{aligned}
& \text { و الصّّ امع بجميع المملكة، فليس فيها مشرك و ولا كافر ينظاهر بكفره؛ }
\end{aligned}
$$

More Jews converted to Islam because of reservation, and preserved their properties but Christians went to Andalusia, and they did not stay except small number of them. Thus, synagogues and monasteries across that land were destroyed, and no pagans and infidels remained in the west to reveal his disbelief. "(History of Islam, vol. 42 , p. 223)

It is implied from some sources such as Hadj travelogues written in the recent hundred years that the people of Hejaz not only were considering reservation as religious terms, but they were considering it a kind of hypocrisy. (Fifty Qajarid Hadj travelogues, corrected by Rasoul Jaefarian, p. 204)

The result is that reviewing on Shia and Sunni sources indicate: 1- any indication cannot be found in Sunni sources in which the term reservation to be used as a religious term, but this term is used in the same pre-Islamic common meaning. 2- The same adventure is also in Shia sources until era of Imam Baqir and Imam Sadiq, and if the word reservation is used in a place, it implies to the same common meaning.

\section{The Concept of Reservation in the Period of Imam Baqir (Pbuh)}

Reservation has allocated an important position to itself in Shia narrative system since the period of Imam Baqir (PBUH) onwards. So that it can be said that the reservation is amongst religious - moral terms Here, reservation addition to have being considered as an act and action, is a religious term with positive valuation. semantic investigation of reservation in Shia narrations shows that although narrations have been quoted from Imams before Imam Baqir and Imam Sadiq (peace be upon them) about the reservation, this term has been semantically transformed since the period of these two great Imams (peace be upon them), and has completely taken valuation meaning to itself. (Continue article)

One of the narrations before the period of Imam Baqir (PBUH) is a narration from Imam Ali (PBUH), which has been in a Jurisprudential ruling:

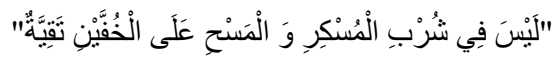


Reservation is not permissible in drinking wine, and anointing feet. "(Vasael Al-shia, 1, 461). Numerous numbers of narrations about the reservation and its prevalence among Shias had been mostly affected by the social and political life of Shias. Behavior of the Umayyad governors after peace with Imam Hassan (PBUH) became strict with Shias and this behavior continued more or less until Omar ibn Abdulaziz (see Ibn Abi Al-Hadid, vol. 11, p. 4346, quoted from Encyclopedia of Islam world) and also during the Abbasid era in another way. Violent behavior of Mutawakkil Abbasi with Shias, and killing and imprisoning them can be mentioned as example.

(Tabari, vol. 9, p. 185; Ibn Jozi, vol 11, p 237) Shia Imams themselves used reservation and recommended this act also to their followers to preserve their lives and Shias' lives, and to prevent the dispersion and collapse of Shia community. We see narrations since this period, which have considered reservation as the condition of faith and piety, and have considered Shias who leave this condition outside the circle of faith and religion.

\section{Semantic Core; First and Second Level Meaning of Reservation}

Now we have information about the reservation that enables us to recognize the meanings of different levels from each other: According to the first information, reservation has two separate periods that has been passed in Shia narrative system and Shia religious - moral system. Reservation in the first period is amongst general vocabulary, and can be hardly considered a Shia or even religious "term". In the second period, this word has found Shia concept and a meaning has been added to its former meaning, and has been changed to a specific term.

According to Izutsu method, moral - religious words are divided into two categories or levels in terms of real semantic core: the first category is descriptive or first level of language vocabulary. These words devoid of any value judgment describe only a verb and objective behavior. A kind of value judgment may be also seen in these words' category, but this is in the second stage. If we look closely, all these words describe only etymology in the first stage.

The second category of vocabulary contrary to the first category contains value judgment before description, and condemns a mood, behavior or action, and somehow shows its indecency and ugliness. Now should be found that reservation belongs to which these two categories. It can be found by looking at the historical and religious narrations in which reservation has been used that the first meaning of reservation is devoid of valuation. In more obvious words, reservation is meant to keep ourselves and is free from any smell and color of valuation at the first glance.

Reservation describes real and objective moral act or behavior without expressing its good and bad. "Concealing belief and faith to protect ourselves" is completely objective and real act that reservation describes the same and does not judge about it. This means it is objective and can be touched as an object and show it. Unlike the valuation meaning that is really an abstract and subjective matter. This is unlike the adventure that can be seen for example in the term "hypocrisy". Comparison of the concept of hypocrisy and reservation that can be considered mutual in a term can be beneficial to clarify the meaning of reservation.

Mismatching of word and deed in matters related to religious faith is the distinctive element of meaning of hypocrisy. (Moral - religious concepts, p. 361) but this does not mean that the same is its first level meaning. Hypocrisy in the first stage denounces an act that is concealing infidelity and polytheism and false statements of religious faith. In other words, valuation aspect of hypocrisy prioritizes and prevails over its descriptive aspect. We also encounter with mismatching of word and deed in reservation, but its scope is not only religious faith.

Any mismatch between word and deed is considered in the main semantic element of reservation and is not specific for religious affairs and religious faith. This has caused that the first semantic level of reservation is free from any value judgment. Value judgment reaching semantic core of reservation is related to the next stages of semantic transformation of this term. In a development which occurred in Islamic period, opposite of the meaning of hypocrisy reached reservation, and this term was allocated to the meaning in which "concealing religious faith" plays an important role. Opposite of the concept of hypocrisy that element of "Concealing disbelief and expressing religious faith," that plays main role in its semantic field.

Concealing belief to protect themselves or whatever is honorable for the user of reservation constitutes the totality of reservation meaning in the primary meaning of reservation, which was widespread among Arabs before Islam. Thus, reservation means the first neutral, and was being used since the pre-Islamic period. This is contrary to the adventure that has been occurred for hypocrisy, Because it seems that the word hypocrisy has been used for the first time for the people of Medina who converted to Islam apparently after the migration of the Prophet(PBUH) and did not believe in heart (moral - religious concepts, 371). It had been with negative valuation since the beginning, in more clear words, valuation meaning is of the first and fundamental elements of 
the term hypocrisy

So it can be said that two elements were added to the meaning of reservation after Islam and Imam Baqir and Imam Sadiq period: First, the "matters related to religious faith" because reservation was being used on the same Arab customary meaning: concealing belief without stating religious faith in term other than Shia term (and even before this period, in Shia term). Second, positive valuation thereby reservation become a religious - moral term in Shia religion. Therefore, reservation in an unprecedented way was mentioned of favorite acts God in numerous narrations from religious leaders.

In fact, at this point of time, we are witnessing the birth of a religious - moral term that implies to one of the most favorite acts of God according to narrations. The following narrative in addition that has revealed being valuation of the reservation in Shia moral system, has also loaded a postural effect on it, and has considered reservation as a source of elation. Postural effect itself is the other evidence on this term has a prominent role in Shia religious - moral system, and is not just a defensive strategy:

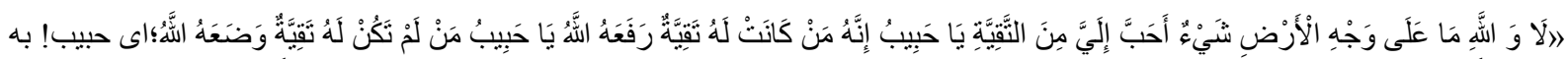

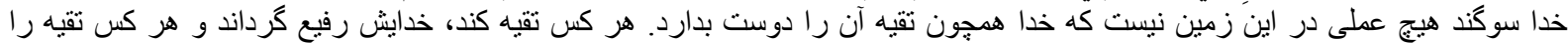

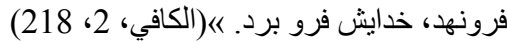

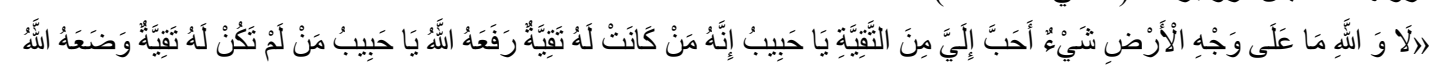

O Habib! I swear to God no act is in the earth that God loves it as reservation. Whoever performs reservation, God makes him lofty and whoever does not perform reservation, God takes him to an inferior position. "(Al-Kafi, $2,218)$

In the following narration, reservation has clearly been stated and introduced as part of the religion that God likes to be worshiped in secret (reservation) as He likes in explicit way. Also this narration well affirms and states the above claim that it seems popularity of reservation has not been just posed in the narrations as a mere defensive strategy and itself is a kind of subjectivism and is considered a religious and worship practice:

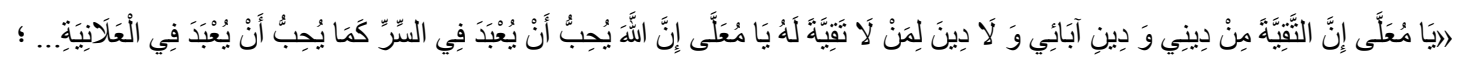

O Mu'alla! Reservation is of my religion and the religion of my fathers. Whoever does not have reservation has no religion. O Mu'alla! Forsooth God likes to be worshiped in secret, as he likes to be worshiped in clear. "(Al-Kafi, 2, 221)

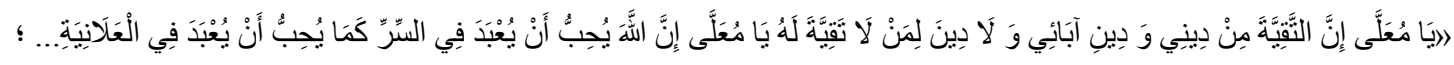

Reservation was also considered condition of piety and religious faith in many other narrations. The following narrations first make reservation companion with piety, and then with faithful. However companionship here does not equal to companionship of two terms and the reservation has been considered as a way to protect piety. But the second part of the narration emphasizes on that reservation is of the number of verbs that are necessaries of faith and principle of faith is not organized without them:

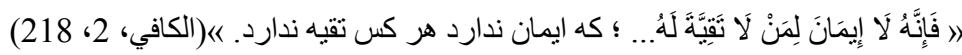

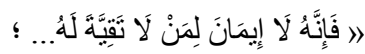

Whoever does not have reservation does not have faith"(Al-Kafi, 2, 218)

\section{Semantic Elements of the Term Reservation}

\subsection{Preservation and Protection}

"تقيه" (reservation) is of material of "V - Q - I" that its first semantic core and basis is to preserve and protect something from risk of something else (Johari, Al-sahah, vol. 6, p. 2527; Al-mofradat, 881). The word "تقو" (virtue) is also of this material in which the meaning of preservation and protection of ourselves against sins is also considered (Lisan al-Arab, 15, 402; Majma Al-bahrein, 1, 449). The semantic mentioned element is in all other derivations of this material. The other meaning that has been mentioned for this material all refer to the same meaning, including:

- Fending off a risk of something from something by something else (Ibn Fars, 6, 131): preservation of something is also achieved in this meaning by fending off a risk.

- Concealing something (Lisan al-Arab, 15, 402): we also conceal something in this meaning thereby we fend off a risk from it and preserve the intended object.

- Avoiding (Lisan al-Arab, 15, 403): man avoids and abstains from something and distances from it in this meaning. As is clear, the meaning of preserving an object from risk is also hidden in avoiding. 
There is a reciprocal relation between faith and reservation in the Shia narrations. On the one hand, faith is a part of semantic core of reservation. On the other hand, reservation itself is of the necessaries of religious faith. Faith is an element that makes the reservation away from the term hypocrisy that is concealing belief or stating belief contrary to the inner reality of man. This is because, as said, mismatching word and deed in matters related to religious faith is distinctive element of hypocrisy (religious - moral concepts, p. 361). This meaning can also be seen in reservation. But there is mutuality between these two.

Reservation is concealing the faith that is in the believer in secret and hypocrisy, is expressing the faith that is not actually in heart of hypocrite. Thus, element of religious faith is hidden in reservation contrary to the hypocrisy in which infidelity is hidden. Reservation is in fact meant to protect and conceal the faith. If we take the element

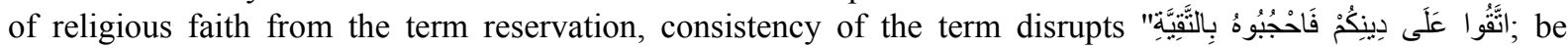
worried about your religion and conceal it with reservation."(Al-Kafi, 2, 218)

Thus, if mismatch between word and deed occurs in faithful person, it is reservation and if occurs in unfaithful person (infidel or pagan), it is hypocrisy. On the other hand, this element of faith distinguishes reservation in common use of Shia from reservation in general sense that is only concealing belief whether religious belief or non-religious belief. Reservation in Shia term community is an act that is done by the believer and faithful person and faith element has been incorporated in the semantic core of reservation.

Now there is another problem and that is what the purpose of faith is and what belongs to the faith in narrations of reservation? Reviewing the narrations reliability makes clear some points to us. In Shia narrations, the quiddity of faith has been changed depending on the opponents. In the following narration, the action of the Companions of the Cave has been mentioned as reservation that their opponents were infidels. In this narration, religious monotheism belongs to faith, and the Companions of the Cave were concealing their faith in God from infidels of those days. Thus, their reservation had been intra-religious. This means they were doing reservation when encountering with their coreligionists:

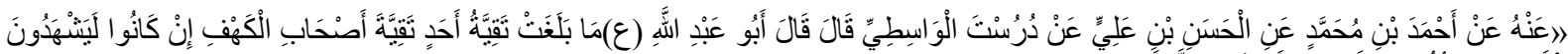

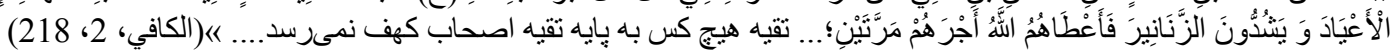

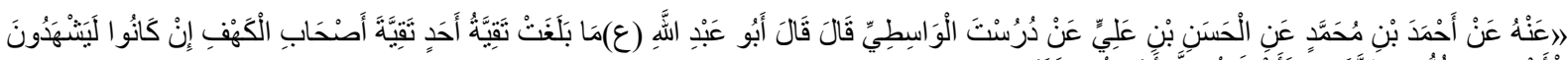

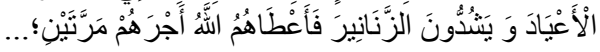

Reservation of no one is at the extent of reservation of Companions of the cave.... "(Al-Kafi, 2, 218)

But in most of Shia narrations about the reservation, pontificate and governorship of innocent Imams (peace be upon them) belongs to faith. In other words, the Shias were utilizing reservation to conceal the matter of pontificate of Shia Imams, as well as their faith from them. This reservation is of the intra-religious reservation because innocent Imams (peace be upon them) and the Shias were doing reservation against damage that may be done on them from the governors of other Islamic sects. This fact is well evident in the following narration from Imam Sadiq (PBUH). The beginning of the narration has stating about concealing the pontificate of Imams and their secrets, and this act has been called reservation in the end:

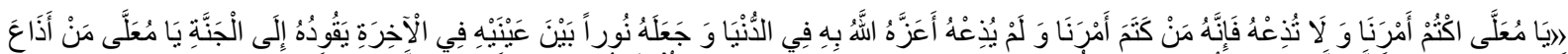

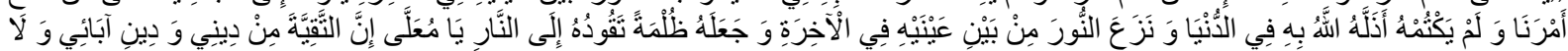

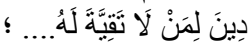

... O Mu'alla! Conceal our matter and do not reveal it that everyone who conceals our matter and does not reveal it, God cherishes him in the world and makes him a light on his way in the Hereafter to reach paradise ... O Mu'alla! Reservation is religion of me and my father and who has no reservation, has no religion.... "(Al-Kafi, 2, 223)

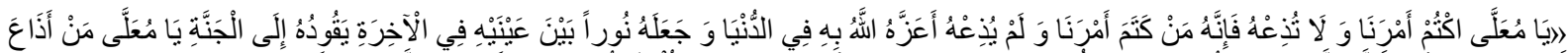

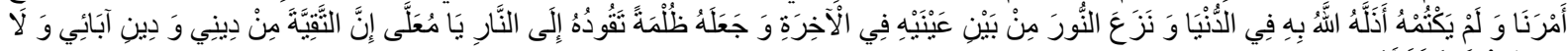

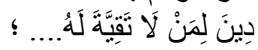

\subsection{Security}

Reservation is a strategy to be preserved. User of reservation creates security for him or whatever is honorable for him by doing reservation. But we should not fall into the wrong that semantic element of security is part of the semantic core of reservation. Security is a meaning outside the semantic core of reservation and is after reservation in terms of temporal primacy and recency and inherent. In other words, it is emerged after the reservation and is not in the reservation itself.

Witness of this claim is that the reservation may occur and happen but does not provide security. This 
assumption arises when, for example, person "A" conceals his reservation and belief, but opposite person of him called "B" does not believe the practice of "A" through a way, and finds that his word and deed does not match with his inner belief, and harms him. Reservation implies only on the protection and preservation as far is in relation with security. This means although it can be the source of security in the real world, it does not have any relation with reservation in virtual world.

\section{Conclusion}

The term reservation was being used before Islam as a general term for act of concealing the belief in order to protect life, property or whatever had been honorable for the user of reservation. Religious belief is not in semantic structure of this word. According to historical narrations, reservation has been used with this semantic after the advent of Islam and is also using now by Sunnis with the same meaning. This term reached narrative system of Shias by semantic development and transformation in the period of Imam Baqir and Imam Sadiq (peace be upon them). The mentioned development was because of social and political pressures that were imported on Shias and especially on the Imams (peace to be upon them) by opponents, and especially by rulers of Muslims. Reservation is a first level term of language in the Shia narrations and describes a real and objective act and behavior. Unlike the term hypocrisy, it deals value judgment, and denounces and condemns ugliness and wrongness to denounce the inadmissibility of the act of hypocrisy before describing. Thus, reservation is related to the first level of language and hypocrisy belongs to the second level of language. It can be found from the usages of the word reservation Shia narrations that reservation while preserveing its semantic core (preserving and protecting ourselves through concealing belief and opinion), it also attracts meaning of religious faith to itself and has become in meaning of preservation through concealing religious belief and opinion. Thus, two meanings of preservation and religious faith play a key role in semantic core of reservation in the Shias narrations. The concept of religious faith in the reservation is about the pontificate and governorship of innocent Imams. Infallible Imams saved the Shia community from the dangers that threaten them by opponent rulers through redefinition of reservation and recommending the Shias to do act of reservation. Thereby reservation was changed to a religious - moral term and positive valuation was added to it.

\section{References}

Abbasi, Mehrdad and Pourakhfam, Maryam, "when used in explaining the ideological concepts of the Qur'an: The concept of God in the look of Izutso", صحيفه مبين, No. 49, Spring 2011.

Al-balazeri, Ahmad ibn Yahya ibn Jabr. (279 AD). كتاب جمل من انساب الأشراف, research by Soheil Zakar and Riyaa Zarkeli,T al-ola, Dar Al-fekr, Beirut, 1417 AH / 1996 AD.

Al-maqrizi, Taqieddin Ahmad ibn Ali, 845) إمتاع الأسماع بما للنبى من الأحوال و الأموال و الحفدة و المتاع, AD ), Research.

Al-Tabari, Abu Ja'far Mohammad ibn Jarir (310 AD), تاريخ الأمم و الملوك، تحقيق محمد أبو الفضل ابر اهيم، ط الثانية، دار التراث, Beirut, 2008 / 1967AH .

Al-Ya'qubi, Ahmad ibn Abi Ya'qub ibn Ja'far ibn Wahab Vazeh Al-kotob Al-Abbasi (292 AD تاريخ اليعقوبى، ، دار ,Beirut, without date.

Al-zahbi, Shamseddin Mohammad ibn Ahmad, 748) تاريخ الاسلام و وفيات المشاهير و الأعلام,AD ), research by Omar Abdul Salam Tadmori, ط الثانية، دار الكتاب العربى, Beirut, 1413/1993.

Fayoumi, Ahmed ibn Mohammed Moqari, المصباح المنير في غريب الثرح الكبير للر افعي، دار الفكر للطباعة و النشر و التوزيع، دار صادر, Beirut - Lebanon, III, 1414 BC.

Fazel Meqdad, Meqdad ibn Abdullah, اللوامع الالهية فى المباحث آلكلامية،, published by Ali Ghazi Tabatabaee, Qom, 2001.

Haddad Adel, Golam Ali. (2006). Encyclopedia of the Islamic World, Tehran, Islamic Encyclopedia Foundation.

Halabi, Ali ibn Ebrahim, السيرة الحلبية, Beirut, offset publication, without date.

Homayri, Nashvan ibn Said, دار الفكر المعاصر, Bol.12, Beirut - Lebanon, the first in $1420 \mathrm{AH}$.

Horr Ameli, Mohammad ibn Hasan, وسائل الثيعة, vol.30, Al-Bayt (peace be upon them) Institute, Qom - Iran, first, $1409 \mathrm{AH}$

Hosseini Farahani, Mohammad Hossein. (2010). fifty Qajar pilgrimage itinerary, travel to Mecca, corrected by Rasoul Jaefarian proofing, Elm publication, Tehran.

Ibn Abi Al-Hadid. (1404 AH.). as Nahj al-Balagha, published by Mohammad Abulfazl Ebrahim, Qom. 
Ibn Jozi. (1412 AH / 1992). المنتظم فى تاريخ الملوك و الامم, published by Mohammad Abdul Qadir Ata and Mostafa Abdul Qadir Ata, Beirut.

Ibn Manzur, Abulfazl, Jamaleddin, Mohammed ibn Akram, Lisan Al-Arab, vol. 15, دار الفكر للطباعة و النشر و التوزيع - - دار صادر - Beirut - Lebanon, III, 1414 AH.

Izutsu Toshihiko. (2009). God and Man in the Quran, translated by Ahmad Aram, Tehran.

Izutsu. (2009). moral - religious concepts, the Ho;y Qur'an, translated by Fereydoun Badrehee, Tehran.

Johari, Esmail ibn Hammad, Al-sahah - دار العلم للملايين, vol.6, Beirut - Lebanon, the first, $1410 \mathrm{AH}$.

Khoee, Seyyed Abul Qasem Mousavi, التنقيح في شرح العروة الوثقى, vol. 6, under Mr. Mostafa Lotfi, Qom - Iran, first, in $1418 \mathrm{AH}$.

Koleini, Abu Ja'far Mohammad ibn Ya'qub, Al-Kafi (T - Al-Eslamieh), دار الكتب الإسلامية, Tehran - Iran, forth, 1407 $\mathrm{AD}$.

Makarem Shirazi, jurisprudential rulINGS, Imam Ali ibn Abi Taleb (PBUH) School, Qom, 1991.

Mofid, Mohammad ibn Mohammad, اوائل المقالات فى المذاهب والمختارات, published by Abasgholi S. Vajdi (Vaez Charandabi), without date.

Mohammad Abdul Hamid Al-namisi, ط الأولى، دار الكتب العلمية, Beirut, 1420 AH / 1999 AD.

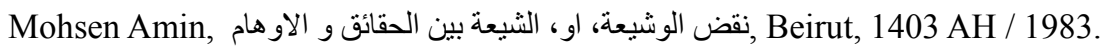

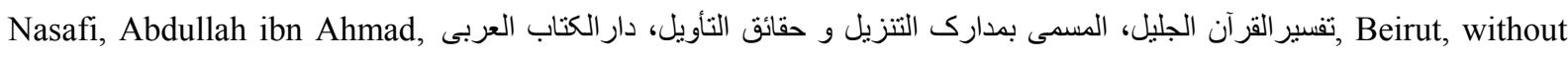
date.

Nejashi, Ahmad ibn Ali, هرست اسماء مصنفى الثيعة المشتهر به رجال النجانشى, published by Musa Shobeiri Zanjani, Qom in $1407 \mathrm{AH}$.

Qortobi, Mohammad ibn Ahmad, الجامع لاحكام القرآن, Beirut, 1405 AH / 1985 AD.

Robins, R. H. (1995). A Brief History of linguistics, Ali Mohammad Haghshenas, Inc. Publishing Center, Tehran.

Safari Foroushani, Nematollah, reservation role in perception, Boostane Ketab, Qom, 2002.

Sarakhsi, Mohammad ibn Ahmad, Al-mabsut, Beirut, Lebanon, Dar Al-marefah, 1414 AH.

Shahrestani, Mohammad ibn Abdul Karim, الملل و النحل, published by Mohammad Seyyed Kilani, Beirut, 1406 $\mathrm{AH} / 1986$.

Soyuti, Abdollah Shabbar, الاصول الاصليَّة و القو اعد الثرعيّة, Qom, 1404 AH.

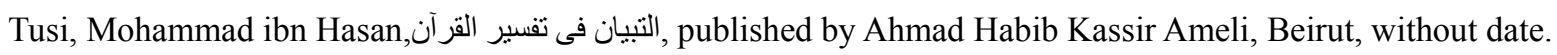

\section{Copyrights}

Copyright for this article is retained by the author(s), with first publication rights granted to the journal.

This is an open-access article distributed under the terms and conditions of the Creative Commons Attribution license (http://creativecommons.org/licenses/by/4.0/). 